\title{
THE ROLE OF FARMING IN MODERNIZATION OF AGRICULTURE IN UZBEKISTAN
}

\author{
Davlatbek Musaev \\ Senior Lecturer at the Department "World History" of Andizhan State University, Andizhan Region, \\ Republic of Uzbekistan
}

Article DOI: $\underline{\text { https://doi.org/10.36713/epra9525 }}$

DOI No: 10.36713/epra9525

\begin{abstract}
The article analyzes the role and place of farms in the modernization of agriculture in Uzbekistan, the systemic reforms in agriculture, their results using primary sources and scientific literature.

KEYWORDS: Agriculture, agro technology, farming, agriculture, State program, modernization, land, reform.
\end{abstract}

\section{INTRODUCTION}

During the years of independence, large-scale reforms have been carried out in the agriculture of Uzbekistan. The Republican government has tried to make more efficient use of the land, which is the main asset in the network, by handing it over to the real owners. Due to this, the number of farms in the village, the amount of land attached to them has increased from year to year. According to the data, farms in the republic have been established since 1989. Initially, this movement was called peasant (farmer) farms. The essence of this movement was that the kolkhoz and sovkhoz allocated land to farmers on a lease basis on a contractual basis, giving them the right to receive 10-15 heads and more of cows. The farmer delivered the products, meat and milk to him at the state price at the expense of fulfilling the economic plan. For the product, the farmer was given mixed feed, construction and other materials. However, the farms established before independence were not independent, formed mainly under kolkhozes and sovkhozes. The kolkhoz and sovkhoz leased land to farmers, but the new form of labor and production was supplemented by the old administrative-command content. This, in turn, has created a situation of skepticism about the possibility of leasing to farmers in agriculture to run an independent farm.

\section{RESEARCH METHODS}

The real farming movement began in the republic after independence. In order to provide state support to farmers less than three months after the declaration of independence, the Decree of the President of the Republic of Uzbekistan dated November 29, 1991 "On further strengthening of peasant (farming) farms and state support of entrepreneurship" was the first step in the release. According to the decree, Uzagroprombank is allowed to provide cash loans to private farms to purchase food and construction materials from the aid fund. On this basis, district, village councils, personal auxiliary economic associations are personally responsible for the targeted use of these funds.

\section{RESULTS AND DISCUSSIONS}

The initial experience of the organization and operation of peasant (farmer) farms in Uzbekistan has been generalized, and a rational mechanism for its development has been developed. The rules of organization and operation of farms are reflected in the legislation of the Republic of Uzbekistan "On Lease" and other decrees, as well as presidential decrees. Based on these rules and initial experiments, it became possible to organize the farm individually and in groups. Farmers are mainly leased and leased land in the manner prescribed by law or exempted from this tax for a certain period of time (due to a natural disaster, etc.) by the decision of the executive committee. Peasant (farmer) farms were exempted from income (profit) tax for the first two years, and then paid $10 \%$ of their income to the budget on a monthly basis. As a result of agrarian reforms, half of the orchards in agriculture and $40 \%$ of the vineyards were given for private use. In particular, more than 14,000 farms have been established, to which 193,000 hectares of land have been allocated. The number of private entrepreneurs reached 300,000 , of which 250,000 were self-employed. The share of farmers in agricultural production has increased. At the beginning of 1994 , there were 14,825 peasant farms in the agricultural system. 


\section{SJIF Impact Factor 2021: 8.013| ISI I.F.Value:1.241| Journal DOI: 10.36713/epra2016 \\ EPRA International Journal of Research and Development (IJRD)}

Volume: 7 | Issue: 2 | February 2022

- Peer Reviewed Journal

There were two different types of farms. The first is that 7,538 independent farms have opened their accounts in the local branches of Tadbirkor Bank. They took a soft loan (loan) from a bank, added their own savings, and bought goods from the market. In the second type, 7,287 farms were part of kolkhozes and sovkhozes, which operated on a contract basis. These farms borrowed from the kolkhoz and sovkhoz and bought cattle and took special care of them. It handed over the products to him at the expense of fulfilling the economic plan at the state price of meat and milk. The state leased land to both types of peasant (farmer) farms. According to the presidential decree, 200,000 hectares of land have been allocated to provide land to farmers. As of January 1, 1994, 162.6 thousand hectares of land had been allocated to farmers, of which 84.7 thousand hectares were irrigated, 20.2 thousand hectares were arable land, 54.2 thousand hectares were pastures and hayfields, and 2.7 thousand hectares were other lands. At the first stage of agrarian reforms, the first foundations were laid for ensuring the stability of the country's agriculture and the transition from a planned economy to a market economy.

The development of horticulture has been identified as a priority. In the network, special attention was paid to the denationalization and privatization of property. In particular, 1,066 state farms (state farms) were liquidated, on the basis of which collective farms were established. In the second stage of the reforms (1998-2004) the laws "On Land Code", "On Agricultural Cooperatives (Shirkat Farms)", "On Farms", and "On peasant Farms" were adopted and implemented. It should be noted that in 1998 the second stage of farm development began. At this stage, farms have achieved true independence. A new period in the activities of farms began after the adoption of the Resolution of the Cabinet of Ministers of the Republic of Uzbekistan dated April 22, 1998 "On the organization of the activities of the Association of Peasants and Farms". This decision was made in pursuance of the Decree of the President of the Republic of Uzbekistan dated April 9, 1998 "On measures to further stimulate the development of private entrepreneurship and medium business" and to increase the role of farmers in increasing agricultural production. In the first stage of the development of farms, they became dependent on collective farms, state farms and companies. In the second stage, they got rid of the addiction. Under the rules of the first stage, a person wishing to become a farmer applied to that farm manager to obtain a plot of land from the land of a collective farm or company. In the first stage, there were insufficient legal and regulatory documents on the establishment of farms. The general meeting of the farm (in practice, the head of the farm) had become a subjective process that depended on the will of the farmer.

At the second stage of farm development, the adoption of the Land Code and the Law of the Republic of Uzbekistan "On Farms", the development of a number of legal and regulatory documents on the establishment of farms, the establishment of farmers' associations, protection of their rights and interests as a result, farms gained true independence and were freed from dependence on company farms. In the second stage of development of farms and peasant farms, the number of farms grew rapidly in 1998-2004. The main reasons for this were measures such as state support for farms, the development and implementation of a mechanism for the transformation of low-profit and loss-making company farms into farms. For example, in 1997 the number of farms in the republic was 21,416 , and in 2004 it was 100,116. During the first seven years of independence, in 1991-1997, the number of farms reached 21.4 thousand. In the three years of the second stage of development of farms, in 1998-2000, their number increased from 23 thousand to 43.7 thousand. In a short time, their number increased to 20.7 thousand. This means that in the first stage of the development of farms, that is, in the first three years of the second stage, almost as many farms were formed as in seven years.

In recent years, farm growth has expanded even further. As a result, the number of farms in 1998-2004 increased almost 21 times compared to 1991-1997, ie from 21.4 thousand to 1001 thousand people [2]. In the second phase (1998-2004), an average of 11.3 thousand farms were established each year. These farms have played a significant role in the production of grain, potatoes, vegetables, meat, milk and eggs, and have become major producers in the cultivation and processing of agricultural crops. In the village, personal subsidiary farms were reorganized as peasant farms. A peasant farm is a small family farm, a plot of land was inherited by the head of the family for life, and agricultural products were grown mainly with the help of personal labor of family members. In 2003, $3.5 \mathrm{mln}$. more than a dozen farms were operating. In accordance with the resolution of the Cabinet of Ministers of the Republic of Uzbekistan dated January 5, 2002, it was planned to establish farms on the basis of 83 loss-making and low-profit farms. According to this decision, agricultural enterprises in Mehnatabad, Mirzaabad and Yazyavan districts of Syrdarya region have been completely transformed into farms. Pursuant to the above decision of the Cabinet of Ministers, 3455 farms were established on the basis of 83 collective farms and company farms, which were allocated 135,300 hectares of land.

In the first nine months of 2002, farms delivered 72,670 tons of grain to the state, or 57 tons more than during the period of collective and company farms. Along with the increase in the number of farms, the area of land attached to them has also increased. The total land area of these farms in 1997 was 413.1 thousand hectares, of which arable land was 260.8 thousand hectares, in 2004 the total land area was 2770 thousand hectares, including 2078 thousand hectares of arable land. This means that during this period the total land area increased more than 6 times, and the sown area increased 8 times. In the first quarter of 2005, there were 116,000 farms in the country, with an area of 3.5 million hectares formed. The average farm area was 28.5 hectares. 765.3 thousand people were employed on farms. According to 2004 data, farms in Kashkadarya, Jizzakh, Bukhara and Syrdarya regions had the highest gross cotton yields. In the same year, the gross cotton harvest in Kashkadarya amounted to 333 thousand tons, in Jizzakh - 232.9 thousand tons, in Bukhara - 172.8 thousand 


\section{SJIF Impact Factor 2021: 8.013| ISI I.F.Value:1.241| Journal DOI: 10.36713/epra2016 ISSN: 2455-7838(Online) \\ EPRA International Journal of Research and Development (IJRD)}

Volume: 7 | Issue: 2 | February 2022

- Peer Reviewed Journal

tons, in Syrdarya - 164.2 thousand tons. Farms in Khorezm, Kashkadarya and Fergana regions have grown cotton at a rapid pace. In 2004, raw cotton in the republic increased 58 times compared to 1997 in Khorezm region, and 33 times compared to 1998 [3].

By 2005, the amount of raw cotton grown by farms in the country increased by 20 times compared to 1997 , and this figure increased by 5 times compared to 2000. The main factor in achieving this is the development of infrastructure serving farms on the basis of the state program. This year, 4,900 farms in the Republic of Karakalpakstan have grown $85 \%$ of the republic's cotton, and 6,037 farms in Bukhara region have grown more than $80 \%$ of the region's cotton. Collective farms and company farms were abolished, and farms based on their lands were specialized in grain growing. The land areas of such farms are mainly allocated for grain crops. As a result, the area under cereals has grown rapidly from year to year. The area under cereals in the republic's farms in 2002 was 385,000 hectares, while in 2003 the figure was 616,000 hectares. The increase in the area under cereals has led to an increase in gross harvest. 78,670 tons of grain were delivered to the state harvest by reorganized farms. This is 1,057 tons more than in the farm period. In particular, the farms of Yazyovan district of Ferghana region have been completely transformed into farms, and during the year the district has grown a total of 24,989 tons of grain from 41.1 quintals of winter grain sown on 6,080 hectares. The plan to produce grain and sell it to state resources has been fully implemented by 110 farms. The average yield on irrigated lands was 48.0 quintals per hectare. In Andizhan region, a high result was achieved - more than 75 quintals per hectare. Thus, thanks to the event held during the years of independence, the independence of grain in the republic has been achieved, the historical task of providing our people with our own grain, our own bread has been fulfilled. This achievement is the result of the renewal of rural life and the ongoing agrarian reforms [4]. The production of flour products, meat and dairy products, sugar and sugar products is steadily growing in the country. Great progress has also been made in the cultivation of vegetables, fruits and grapes. $5 \mathrm{mln}$. tons of vegetables and fruits are grown. After the independence of the Republic of Uzbekistan, in the process of radical economic reforms in agriculture, state farms were transformed into collective and company farms, livestock farms, cattle farms of most farms were privatized, and peasant and livestock farms were established. In order to develop the livestock sector, the Cabinet of Ministers of the Republic of Uzbekistan on March 15, 1993 "On measures to deepen economic reforms in animal husbandry", February 23, 1994 "On measures to improve economic reforms in animal husbandry and protect the interests of peasant farms and privatized farms". March 24, 1995 "On measures to continue privatization in animal husbandry and support private entrepreneurship". According to these decisions, in 1995, 1,499 cattle farms operating at a loss to collective farms were privatized. As a result, $75 \%$ of the meat and milk produced in the country began to be supplied by the private sector. Along with the livestock sector, beekeeping and silkworm breeding have also developed. At present, more than $80 \%$ of industry, $88.4 \%$ of construction, $96.6 \%$ of communications, $99.9 \%$ of agriculture and almost $100 \%$ of trade are in the private sector. The private sector accounts for more than 75 percent of GDP. As noted at the January 18 meeting of the Cabinet of Ministers of the Republic of Uzbekistan, in 2012 alone, the country's GDP increased by $8.2 \%$, industrial production by $7.7 \%$, agriculture by $7 \%$ and retail trade turnover by $13.9 \%$. The main part of total government spending, ie about $59.2 \%$, was directed to the implementation of social and social protection measures, more than $34 \%$ of which was directed to the financing of education, more than $14.5 \%$ to health care [5].

In 2012, the republic's economy received 11 billion soums. $700 \mathrm{mln}$. dollars in domestic and foreign investments, or an increase of $14 \%$ compared to 2011. Such economic growth can also be seen in the example of the provinces. In his speech at the special session of the Andizhan Regional Council of People's Deputies on April 26, 2013, the First President of the Republic of Uzbekistan Islam Karimov said that over the past seven years the region's gross regional product has doubled, industry 2.3 times, agriculture 1.6 times. He noted that construction work increased by 7 times and 3.4 times. In 2005-2012, $224.5 \mathrm{mln}$. about \$ 174 million in foreign investment. \$200,000 in foreign direct investment was disbursed. The number of enterprises with foreign investment was 86 . These enterprises accounted for about $79 \%$ of GDP and almost $89 \%$ of total exports. In 2012, Andizhan farmers were the first to fulfill their contractual obligations, growing 293,000 tons of cotton and 508,000 tons of grain. Since 2013, the number of enterprises operating in the field of small business and private entrepreneurship in Andizhan region amounted to 22,200 , which involved more than $80 \%$ of the population. In particular, "If $80 \%$ of the population of Andizhan lives on entrepreneurship," said the First President Karimov, "tell me, what other incentives can be used to attract people to this field?" [6]. Emphasizing the need to widely promote the experience of Andizhan throughout the country, the First President said: "It is noteworthy that today such positive changes can be seen and observed in the entire Andizhan region, both in villages and cities. We all know and appreciate that you are proud of such achievements, but do not fall in love with them, and live in the spirit of achieving new goals and constantly moving forward. I would like to emphasize one point: If he wants to be informed, let him come to Andizhan first and get acquainted with the work, life and current achievements of the people who call themselves Andizhan". In the "Strategy of actions on five priorities of development of the Republic of Uzbekistan for 2017-2021", approved by the Decree of the President of the Republic of Uzbekistan No. PD-4947 dated February 7, 2017, consistent modernization of agriculture great attention was paid to development. The Action Strategy identifies the development of diversified farms as one of the important factors for the sustainable and efficient development of agriculture in the future. It was recognized that it is expedient for them not only to cultivate agricultural products, but also to process them in 


\section{SJIF Impact Factor 2021: 8.013| ISI I.F.Value:1.241| Journal DOI: 10.36713/epra2016 ISSN: 2455-7838(Online) \\ EPRA International Journal of Research and Development (IJRD) \\ Volume: 7 | Issue: 2 | February 2022 \\ - Peer Reviewed Journal}

depth, to provide various works and services to the population. This, in turn, helps to increase their competitiveness by strengthening their financial stability and solvency. In particular, in 2017, a total of 23,846 farms were involved in the processing of agricultural products, the provision of various services, the creation of intensive orchards and vineyards, the development of the livestock sector with a total value of 1762203 million soums. 25,506 projects worth UZS [7] were implemented. The action strategy includes the creation of favorable conditions for the development of diversified farms, the creation of a regulatory framework for diversified farms in order to ensure their economic efficiency and financial stability, support them with soft loans from the state, preparation and processing of agricultural products. , the development of farm cooperation in storage and sale, the establishment of small enterprises and their departments for the production and processing of products in rural areas. In accordance with the Resolution of the President of the Republic of Uzbekistan dated October 10, 2017 "On organizational measures for further development of farmers, dehkan farms and landowners", support in the field of storage and sale, including the implementation of agro-technical measures and the conclusion of contracts, the provision of comprehensive assistance in the export of products to foreign markets [8].

\section{CONCLUSION}

In summary, farms established in the early years of the farming movement were mainly specialized in animal husbandry and vegetable growing. During the years of independence, farms have shown their superiority over other categories of agricultural enterprises. The establishment of farms in place of the existing company farms has led to great success in cotton and grain growing. The government has paid special attention to providing farms with new agricultural machinery, and mini-tractors have been produced for farms in the Tashkent Tractor Park. The introduction of scientific and technical advances in cotton and grain production has helped farms to improve the quality and quantity of these crops. At the same time, as a result of the care provided to farms by the government of the republic, their rational use of land, water, machinery and other material and financial resources, productivity has increased from year to year. These farms have achieved high results in the cotton and grain sectors, primarily due to the increase in their material interests as a result of their labor.

\section{REFERENCES}

1. Karimov I.A. Our main goal is to sharply deepen the ongoing reforms and structural changes in our economy, to open the way for private property, small business and entrepreneurship.-Tashkent: Manaviyat, 2016

2. Current archive of the Ministry of Agriculture of the Republic of Uzbekistan, compilation of 3-4 minutes of the board meeting of 1994. Page 129.

3. Current archive of the Ministry of Agriculture of the Republic of Uzbekistan, compilation of 3-4 minutes of the board meeting of 1994. Page 134.
4. Collection of the legislation of the Republic of Uzbekistan.Tashkent: Adolat, 2004, No. 52.

5. Karimov I.A. Serving for the happiness and great future of our motherland is the highest happiness.-Tashkent: Manaviyat, 2016. -P.142.

6. Mirziyoev Sh. M. Our main task is to glorify the work of agricultural workers, who are the creators of our livelihood, to raise the development of the industry to a new level // Speech of the President of the Republic of Uzbekistan Sh. Mirziyoyev at the solemn ceremony dedicated to the Day of Agricultural Workers // Agriculture of Uzbekistan.-Tashkent, 2017 .-№12 .-p.2.

7. Decree of the President of the Republic of Uzbekistan No. 4947 "On the Strategy of Actions for the Further Development of the Republic of Uzbekistan" // Khalk Suzi, February 9, 2017.

8. Mirziyoev Sh.M. Report of agricultural workers of Uzbekistan // Khalk suzi, December 9, 2018. 